\title{
A Research Into Iran-Russia Cooperation During the Syrian Crisis
}

\author{
Reza Piramoun Sharifabad* \\ M.A. Student of International Relations and Diplomacy, Shanghai University
}

*Corresponding Author: Reza Piramoun Sharifabad, M.A. Student of International Relations and Diplomacy, Shanghai University

\begin{abstract}
Considering the importance of political and security developments in the Middle East, the present research aims to study Iran-Russia cooperation in the fight against terrorism in Syria.Both countries share this view that the eastward expansion of NATO or a crisis of any type in Central Asia, the Caucasus, and the Middle East will threaten their national security. Discussing the roots of Syrian crisis and the rise of ISIL (Islamic State of Iraq and the Levant), this paper also explains how these events paved the way for a concerted effort and cooperation between Iran and Russia. Accordingly, the discussion that follows is based on historical facts, official statements by the authorities of the two countries, and studies mainly conducted by Russian and Iranian authors and other scholars as well.

In short, the current study is an attempt to approach the topic from different perspectives in order to better understand their motives and road map regarding the Syrian crisis. Finally, the present paper seeks to find out whether the cooperation between Iran and Russia in Syria will lead to a strategic alliance.Accordingly, it is argued that as long as their main factors of cooperation persist, such cooperation may have the potential to form a strategic alliance.
\end{abstract}

Keywords: Middle East, Radicalism, Syrian Crisis, Iran-Russia Cooperation

List of Acronyms: AQI: Al-Qaeda in Iraq, CIS: Commonwealth of Independent States, EU: European Union, IRGC: Islamic Revolution Guards Corps, ISIS/ISIL: Islamic State of Iraq and the Levant, NATO: North Atlantic Treaty Organization, SNC: Syrian National Council, UN: United Nations, UNSC: United Nations Security Council, USSR: Union of Soviet Socialist Republics

\section{INTRODUCTION}

After the collapse of the Union of Soviet Socialist Republics (USSR), Iran-Russia relationship entered a new stage and has experienced many vicissitudes so far. In fact, there have been a series of shared goals and interconnection in various political fields between post-revolution Iran and post-soviet Russia. For instance, issues concerning the central Asia, Afghanistan, Caspian Sea and the Caucuses, and opposing the US unilateralism can be mentioned. Iran and Russia have always been the main and influential poles in the Middle East, whose closeness and convergence could mean a historic and long-termalliance in this sensitive period of time. Cooperation in resolving the Syrian crisis has opened a new chapter in Moscow-Tehran bilateral relations. Prior to the Syrian crisis, Iran and Russia had a history of cooperation in Afghanistan and Tajikistan crises, but their collaboration on the Syrian case is of crucial importance for a variety of reasons. In neither of the past crises has Iran-Russia cooperation been sensitive or worrying to other regional or trans-regional powers.

With the onset of the Syrian crisis in 2011, two different alignments were created in the Middle East. On the one hand, the US, Saudi Arabia, Turkey, and some other Arab countries insist on ousting Bashar al-Assad from power, supporting the opposition groups. On the other hand, Russia, Iran, and Iraq, while supporting the Syrian government, emphasize the need to play an active role in fighting the terrorist groups, namely the armed Jihadi terrorists such as al-Nusra, al-Qaeda affiliates, and ISIS.

For the sake of their own national security as well as various geopolitical reasons, both Iran and Russia cannot turn a blind eye on developments in Syria. In any case, Syria and its uncertain future play a central role in the foreign policy of Iran and Russia, making them work closely together; therefore, Tehran and Moscow have found a number of common grounds to enhance their cooperation 
level, adopting parallel political stance towards regional issues. Accordingly, in the present article, we intend to study Iran and Russia's goals and strategies in the Syrian crisis as well as their conflicting interests and differences.

\section{SYRIAN CRISIS}

The roots of Syrian crisis can be traced back to widespread protests, which began on January $26^{\text {th }}$, 2011 based on ethnic divisions[1]. In addition to important internal factors, such as sectional-religious conflicts, a series of external aggravating factors caused the crisis in Syria. According to Sheikhol Eslami and Beiki, although the freedom of speech and press are addressed in the Syrian constitution, such freedom has been limited since the Ba'ath Party came to power in 1963[1]. Other scholars believe that the main cause of the protests against the Syrian political system is rooted in a chain of revolutions, called "Arab Spring[2]." Inspired by these revolutions, the opponents of the Syrian government first put forward their demands through peaceful demonstrations; however, resorting to foreign dissidents on the one hand, and the violent acts of the Ba athist security apparatus against the protestors on the other hand provided grounds for regional and trans-regional powers to step in the turbulent situation[2].

Some analysts attribute the uprising exclusively to popular movements in the Middle East and North Africa, in which Syrian people, like some other Arab countries experiencing revolutions, suffered social, economic, and political problems and therefore revolted against Bashar al-Assad. This level of analysis does not take a strategic look at the Syrian issue and only considers internal variables involved[2].The nature of these developments is essentially different from what we observed in Tunisia, Egypt, and Libya that was named Islamic Awakening or Arab Spring; rather, it occurred as a result of regional strategic and geopolitical rivalries[3]. While the popular uprisings in Tunisia, Egypt, and Libya were described as native-born and independent, the Syrian rebellion lacked such characteristics, the evidence of which would be the Syrian National Council's (based in Turkey) call for foreign countries to take actions in Syria based on Libyan model[3]. As clearly stated in the official website of the Syrian National Council (SNC), "working towards overthrowing Assad by all available means[4]" is among the basic principles of this council. The SNC seeks to gather support, specifically political support, for the Syrian revolution beginning with the Arab League and then increase support by reaching out to the European Union, the United States, the United Nations, and other nations across the globe[4].

Syria has a special strategic and geopolitical place in the axis of resistance ${ }^{1}$. As mentioned earlier, since the beginning of the crisis, some direct and indirect factors have been involved. On the one side, we see the Arab Union, the Persian Gulf Cooperation Council specifically Saudi Arabia, Turkey, and Israel that declared their full support for the protesters, continuing their attempts to exert influence as well as to manage the protests[5]. On the other side, Iran, Hezbollah and Lebanon, and Iraq strived to keep Bashar Assad as the legal president of Syria[5]. The support for the anti-Assad groups include sending troops, forming paramilitary groups, recruiting mercenaries, sending weapons and donations, political pressure against the Syrian president in regional and international assemblies, and media support[6].

\section{RADICALISM AND THE RISE OF ISIS}

The Islamic State of Iraq and the Levant (ISIS=ISIL) is a terrorist group, known for its Salafi-Jihadi beliefs. Similar to al-Qaeda, the ideology of ISIS draws a great deal from Wahhabism[7].Wahhabism or Salafism is a branch of Sunni Islam practiced by those who follow the teachings of Abd-al-Wahhab (1703-1792 C.E.), and it is the dominant form of Sunni Islam found in Saudi Arabia, Kuwait, and Qatar, as well as some pockets of Somalia, Algeria, Palestine, and Mauritania[8]. In other words, being a Salafi or Wahhabi is related to Ibn-Taymiyyah's reading of Islam and Wahhabis generally interpret the religion on the basis of Ibn-Taymiyyah and Abd-al-Wahhab thinking foundations[9]. Wahhabism relegates women to the status of second-class citizens, and regards Shia and Sufi Muslims as non-Muslims to be persecuted along with Christians and Jews[10]. In this ideology, rationalism is decried and the ISIS jihadists regard democracy as Kufr (unbelief)[11]. They regard their self-

\footnotetext{
${ }^{1}$ This term refers to an alliance among Iran, Iraq, Syria, Hezbollah, and Houthis, which aims to oppose the USIsraeli and Saudi coalition.
} 
proclaimed caliphate (Islamic State) not only for one particular country, but for all Muslims in the world[11].

After the US invasion of Iraq in 2003, Abu Musab al-Zarqawi founded al-Qaeda in Iraq (AQI) to fight against the American forces and was responsible for a series of bombings and attacks during the Iraq War[11]. Later, Abu Bakr al-Baghdadi began to appear from the shadows in the summer of 2010 when hebecame leader of AQI after its former leaders were killed in an attack by US and Iraqi troops[10].

Led by al-Baghdadi, ISIS gained significant conquests and took over large parts of Iraq and Syria in a short time. As Cockburn elaborates, the terrorist group "covered an area larger than Great Britain and inhabited by 6 million people-a population larger than that of Denmark, Finland, or Ireland. In a few weeks of fighting in Syria, ISIS had established itself as the dominant force in the Syrian opposition[10]."

\section{SECURITY THREATS OF ISIS TO IRAN}

Following its swift advance, ISIS captured two cities in the Iraqi province of Diyala, namely "alSadiyah" and "Jalawla" in eastern part of Iraq, which are in close proximity to Iran's Khosravi border[11]. The terrorist group's proximity to Iranian borders, as well as the likelihood of its access to middle-range weaponries would take on new security dimensions. On December $10^{\text {th }}, 2015$, four baby dolls rigged with explosives were discovered in Kashmar city of Iran which had been purchased by a family coming back from Iraq[12]. A similar event had happened just 20 days earlier in Iraq when the Iraqi army units found Daesh (ISIS) explosive dolls on road to Karbala, where pilgrims pass through[13].On June $7^{\text {th }}, 2017$, a group of gunmen launched simultaneous attacks on Iran's parliament building in downtown Tehran and on the mausoleum of the late founder of the Islamic Republic Ayatollah Khomeini, south of the city in which 17 people were killed and more than 40 wounded[14]. The ISIS claimed responsibility for the attacks and some days later, Iran's Islamic Revolution Guards Corps (IRGC) reacted by launching missile strikes against the ISIS military base in the Syrian town of Deir ez-Zour[15].

Andrew Korybko, an American Moscow-based political analyst believes that by doing this operation in Tehran, ISIS was seeking revenge against Iran for its decisive support in helping the Syrian Arab Army cripple the terrorists in their own self-declared "caliphate"[16].Mentioning a number of other similar terrorist attacks, including assassination of Iranian nuclear scientists, Mojahedin-e Khalq Organization's attacks, and the latest attacks in the country's parliament and Ayatollah Khomeini mausoleum, Korybko argues that these are a testimony to the fact that Iran has been a major victim of terrorism[16].

As ISIS does not recognize the political borders, in addition to being an international and regional threat, its discourse and actions particularly pose a serious threat to Iran's national security and interests. Based on its ideology and long-term plans, ISIS has drawn its own map of the world to expand the Islamic State territory all throughout Europe, Asia and Africa[17].

\section{SYRIA'S STRATEGIC IMPORTANCE FOR IRAN}

The alliance between Iran and Syria must be studied not only in their common national interests, but also in the tactical and strategic interests between the two countries[18]. Iran-Syria special relations dating back more than three decades, have been hampered by the crisis in Syria and influenced by the Arab revolutions. Those states criticizing Iran's foreign policy believe that Tehran has adopted two completely different approaches towards the uprisings in Bahrain and Syria; supporting the protestors in Bahrain against the Al-Khalifa regime on the one hand, and emphasizing on Assad staying in power on the other hand[19]. In response to the above criticism, Iran points out that unlike Bahrain, where the majority of the population opposes the ruling regime and only a minority supports the rulers, the issue is completely the opposite for Syria[19]. In Syria, the opposition groups mostly comprise of fully armed Jihadi terrorists such as al-Nusra, al-Qaeda affiliates, and ISIS which if replacing the current Syrian government, a serious persistent threat would devour and annihilate not only the whole Middle East, but also the world[19]. In this regard, Moscow views Arab revolutions as popular movements but with Western manipulations, deviating from their intended original course[20]. 
Alexander Dugin, professor of Moscow State University, shares the same viewpoint and believes thatthe Arab spring is not related to the interests of the Arab world itself. The Arab Spring is the manipulation of American strategists to change the balance of power in the Middle East[21]. The aim of the Arab spring is to support what is called regional subimperialism in modern geopolitics, that is, US allies (Qatar, Saudi Arabia among the Arab countries, and Turkey) that act as intermediaries for operations in the interests of the United States[21].

In an article, named "Russia and the Changing World", the Russian President Vladimir Putin corroborates the above argument[22].

After the Iranian Revolution in 1979, the anti-Zionism policy became one of the central pillars of Iran's foreign policy and Tehran's close ties with Damascus reached its highest level. In addition, another key factor that had led Iran to strengthen its relations with Syria is the latter's firm stance and policies towards Hezbollah in Lebanon. In other words, the main factor for the closeness of Iran-Syria relations is their similar policy towards the Zionist regime and support of Hezbollah[20]. Hezbollah plays a key role in Iran and Syria's foreign policy and by their help; it has been able to resist Israel both politically and militarily[20].

While a number of political analysts believed that Iran's support of Bashar Assad would gradually decrease and Tehran would either change or balance its stance in order to be considered as one of the stakeholders in the new Syrian government, Iran surprised other actors by continuing its unremitting support for Assad[23]. While supporting the demands of the Syrian people, the Islamic Republic stresses the need for reforms in Syria[23].

On the other hand, Iran pursues several other goals, such as preventing similar incidents in the Middle East, impeding Israel's influence in the region, maintaining Shiite alliance, and keeping a geopolitical balance in the region. From this perspective, in the event of Bashar al-Assad's fall, it is unlikely that his successor government would be in harmony with the Islamic Republic of Iran in pursuit of regional goals[24]. From another point of view, Nejat and Jafari argue that Iran views Syria as the "Frontline of the Axis of Resistance" where it has been turned into an arena of flamboyant display of military power[25]. In other words, Syria has become a center of conflicting interests of the Western countries and their allies in the Middle East against the axis of resistance[25]. The coalition created by Iran, Syria, Hamas, and Hezbollah obstructs the goals of the US, Israel, and Saudi Arabia in the region and if Syrian government is overthrown, the above coalition and Iran's soft power will certainly diminish[26]. The strategic importance of Syria can be summarized as follows: Being located at the junction of the three continents (Asia, Europe, and Africa); Neighboring with Iraq, Lebanon, Israel, and Turkey as the important geopolitical components of the region; An Arab country with independent relations both regionally and internationally; A gas and oil transit passage for Iran and Iraq to Europe; And finally, a country that influences the political equations in Lebanon[26].One of the threats posed by the Syrian crisis for Iran is regional instability and insecurity coupled with the intensification of ethnic-religious conflicts arising from extremist groups. Once the Syrian crisis began, the importance of Iran-Syria relations took on new security aspects and created an axis which included Iraq and Lebanon as well. Considering the above-mentioned factors, while striving to fight the Takfiri-Jihadi terrorists, Tehran aims to prevent the order intended by the US, Israel, and Saudi Arabia in the Middle East.

\section{SYRIA'S STRATEGIC IMPORTANCE FOR RUSSIA}

At the beginning of the Syrian uprising in 2011, Russia remained only an observer and except for some verbal support for the Syrian government and its 2013 chemical weapons proposal, Moscow did not provide Syria with any significant logistic and military assistance[27]. With the onset of the Ukraine Crisis and the intensification of European sanctions, Moscow realized that the time for being indifferent was over and it was the best opportunity to take immediate action to counter the unipolar system and sustain a multipolar order with multilateralism[27]. The 2000 edition of foreign policy concept of the Russian federation emphasizes the necessities of achieving a multipolar world and rejects the unipolar system[28]. In the Syria case, Moscow seeks a collective decision and opposes unilateralism. It should be noted that the pursuit of a multipolar world model is not limited to Putin, and Dmitry Medvedev repeatedly cited it as one of the fundamental strategies of the Russian foreign policy. In an interview with a Russian TV channel, Medvedev stated, "We cannot accept a world order in which onecountry makes all the decisions, even as serious andinfluential a country as the 
United States of America.Such a world is unstable and threatened by conflict"[29]. As the clashes escalated in Syria and due to the terrorist groups advance and danger of imminent attack on Syriancontrolled areas, including Latakia (where Russia's main military base is located), Moscow responded to Bashar al-Assad's call for military action[27].

Moscow's decision for direct military involvement in Syria through air strikes on the bases of ISIS greatly enhanced Russia's role in Syrian developments. Russia's effective presence in these developments brought Moscow closer to Tehran, which, like Moscow, backed Bashar al-Assad's government and opposed a regime change.

Mehdi Amiri maintains that Russia's entry into the crisis was realized though high level coordination and consultation with Iran[30]. Some sources report Qassem Soleimani's (IRGC Quds Force Commander) visit to Moscow in July 2015 as instrumental in precipitating the deployment of Russian combat forces in Syria[31]. In this regard, a Russian commentator notes that this visit, although later denied by the Russian officials, caused a serious concern in Washington[32].

Undoubtedly, much of the Russian Federation's concerns over the Syrian crisis derives from its political interests and strategic considerations in the region.Kremlin officials well know that after the collapse of the USSR and the end of the Cold War, Russia lost much of its influence in the Middle East; therefore, in order to regain its prestige and have a decisive influence on regional equations, it can only count on Assad's regime[33]. Given Russia's good relations with Syria, in the current situation, the latter remains the only base for Russian involvement in the Arab world and in the Middle East[34]. On the other hand, Russia's intense rivalry with the West to curb the expansion of US and European influence in the strategic regions such as Central Asia and the Caucasus has led Moscow to push its conflict with these countries further afield and focused on the Middle East[34]. Alternatively stated, Russia has strived to shift the battlefield away from its direct security regions (i.e. Near Abroad) to other regional crises like that of Syria[34]. In addition, if Russia's pivotal role in the Syrian Crisis leads to the final defeat of Assad's opposition, this can prove Russia's capability to resolve regional crises and enhance its political prestige[35].

Kremlin opposes the military intervention of the West in Syria, because it believes such intervention will cause the Libyan scenario to be repeated in Syria. In this regard, the Russian foreign minister, Sergei Lavrov stated that Syria should not experience the fate of Libya, otherwise, years will have to face the consequences, and changes in regimes cannot be achieved at the cost of cooperation with terrorists[36].Putin seemsto view the Russian image of being a steadfast ally as important internationally for the credibility of Russia's other political alignments, such as with the CentralAsian states of the Commonwealth of Independent States (CIS)[37]. The touchstone of such credibility is support for Russia-friendly leaders and their entourage, or atleast a refusal to accede to western campaigns to unseat them[37].This is not to say that the Russian leadership feels no affinity with the communities caught up in the bloodletting in Syria[37].Some have argued that Putin is influenced by the Russian Orthodox Church, which fears that Syrian Christians, among them a large body of Orthodox, would be persecuted if Islamist factions came to power in Syria[37].

Tartus naval base, located on the Syrian coast, is one of the main incentives for Russia's military involvement in the Syrian crisis to protect its strategic interests.Because of its defensive position, Tartus is of crucial importance to Moscow, allowing the Russian naval vessels a permanent base in the Mediterranean[38]. In that sense,losing the base will lead to the loss of Russian influence in the Mediterranean Sea and even of options for the continuous presence of Russianships in more distant oceans[39].Another Moscow's major concern with Syria is that the crisis escalates and that the wave of terrorism and extremism reaches the former Soviet republics, regarded as "Russia's backyard"[34]. The so-called "Near Abroad" countries, specifically the Central Asian Republics and the Caucasus have great potentials to be influenced by the radical Islamists arising from the Syrian crisis, something of which Russia is heavily afraid[40]. Additionally, the population of millions of Muslims living in the above-mentioned countries and due to Russia's poor record of treatment of Muslims in the Chechnya and Kosovo crises could create an anti-Russia atmosphere and provide an arena for Moscow's strategic rivals, the West and the US, in that region[41].

It is worth mentioning that since the beginning of the crisis, Russia has vetoed several Security Council resolutions against Syria, the most important of which was Resolution 7180 on 22 May 2014 
that was supposed to refer Syria to the International Criminal Court[42]. This may indicate the importance of Syria for Russia that makes all the effort to keep Bashar al-Assad.

\section{IRAN-RUSSIA COOPERATION IN SYRIA}

One of the prominent features of relationship among actors in the international politics is being "relative", and this feature regulates the goals and interests of each country in determining a "friendly", "hostile", or "neutral" relation with other states[43]. Obviously, the Iran-Russia relationship is no exception. In fact, the ups and downs of relations between the two countries over the past several centuries should also be examined in the above-mentioned principle, which brought the two sides either closer or apart at different historical times. The rapid and complicated developments in the Middle East, especially Syria, are historic milestones for Tehran and Moscow, which despite the differences between the two countries, have led to significant points in their relation.

For various historical and geopolitical reasons, and in order to maintain their own national interests and security, both Iran and Russia are opposed to the expansion of the political, economic, and military influence of the Western world in their vicinity. Hence, in recent years, Tehran and Moscow have taken similar critical approaches towards the US unilateralism, NATO expansion to the East, deployment of anti-missile system in Czech Republics, Poland, and Turkey, and color revolutions.From this perspective, Syria's current developments are considered Iran-Russia common concerns of the expansion of the Western influence in the strategic region of the Middle East. On the one hand, Iran sees Syria as an important point in the Axis of Resistance against the US and Israel, and on the other hand, Russia follows its own long-term goals and interests in Syria, therefore, emerging a pro-western government after the fall of Assad will never be in line with the interests of Iran and Russia.

Another fact that let to Iran-Russia cooperation in the Syrian crisis is that they both share serious concern over Salafi-Wahhabi radicals coming into power that could both threaten Iran's national security and its regional allies, and destabilize the North Caucasus and all the regions under Russia's influence.

On September 28, 2015, during a speech at the 70th session of the UN General Assembly, Vladimir Putin officially announced the initiative to create a broad front to fight the Islamic State terrorist group in Syria and Iraq[44]. On September 26, 2015 Russia, Iraq, Iran and Syria created an information center in Baghdad to combat the Islamic State[44]. The main functions of this structure were the collection, processing, synthesis and analysis of current information on the situation in the region in order to fight terrorism[44].

Konstantin Kosachev, chair of Russia's Committee on International Affairs said in March 2017 that the successful anti-terrorist cooperation between Russia and Iran has become the basis for the development of relations between the two countries in various aspects, including in the economy and humanitarian sphere[45].Calling Iran-Russia cooperation in Syria a "brotherly fight", Kosachev presumed that the level of bilateral cooperation has been fixed at a very high level[45].

In a visit to Tehran in November 2017, the Russian President Vladimir Putin called the collaboration with Iran on the Syrian issue "productive"[46].Russian Deputy Foreign Minister Sergei Ryabkov also stated that there are no contradictions between Russia and Iran over Syria[47].Ryabkov reiterated that the Astana talks indicate that Russia and Iran have a high degree of mutual understanding[47].

The logistics and operational coordination between the Iranian and Russian forces in Syria paved the way for the enhancement of their military cooperation from export of weapons and equipment to a higher tactical level[48].Undoubtedly, this cooperation would enhance Iran's geopolitical weight and strengthen its presence as a powerful actor. Similarly, Russia could pressure the US and the European countries to modify their policies in sanctioning Russia over Crimea and Ukraine Crisis[48].

The Syrian crisis and rise of ISIS has changed the nature of Iran-Russia relations from a relatively superficial framework to a highly active form in line with their geopolitical interests. This transformation has created almost a degree of political equality in bilateral relations, adding to the importance of Iran's role in regional and global politics[48]. Such defense-military agreements between Iran and Russia have had a major impact on the regional and trans-regional countries, as well as the geopolitics of the Middle East; therefore, we might call this a strategic partnership[48]. 


\section{CONFLICTING INTERESTS AND CHALLENGES OF COOPERATION IN SYRIA}

Significant military cooperation between Iran and Russia in Syria has created trust between the two countries and opened a new chapter in their relations. However, it seems that they do not totally agree on a number of issues and the future of Syria.

The fate of Bashar al-Assad is a long-term conflicting goal for Iran and Russia, where the former insists on maintaining Assad as the legitimate Syrian president, rejecting his deposal, while the latter has shown to be more flexible on this issue."Assad is not our ally, by the way. Yes, we support him in the fight against terrorism and in preserving the Syrian state, but he is not an ally like Turkey is the ally of the United States," Lavrov said[49].This is precisely the point of difference between the strategy of Tehran and Moscow in the Syrian war . Mohammad-Ali Jafari, an IRGC commander stated that "Bashar al-Assad patronizes the Resistance Front and we have no one there after him. The resistance in Syria depends on al-Assad, and we cannot ignore this.[50]"Russia's strategy is based on safeguarding its interests in relation to international powers and Assad can stay in power but not at any cost[43]. What we can infer from the Russian officials' statements is that Assad is not their red line and any non-extremist government that can maintain stability in Syria is acceptable to Russia. Such approach may cause serious discord in the long run between Tehran and Moscow in Syria[43].

Another fundamental difference in Iran-Russia relations in Syria is the Russian-Israeli bilateral relationship.Israel is deeply concerned about Hezbollah becoming stronger in Syria and in its borders[43].In its cooperation with Iran in Syria,Moscow also takes into account the Zionist regime's considerations and apparently assured Israel that its interests would not be harmed[51]. In Syria, Russia seeks to preserve its geopolitical position in the Middle East and Mediterranean to influence the regional equations, while Iran looks at Syria as one of the pillars of the Resistance Front, something that Moscow does not believe in and might even oppose[51]. In this regard, Maysam Behravesh explains the situation as follows: "Iran also seems determined to forge a new layer of deterrence in its asymmetrical regional security structure by using Syria as a forward base to balance against Israel. This is what has come to be known as Iran's policy of "strategic depth" — that is, to take the fight as close to enemy territory as possible.[52]"Behravesh further argues that this approach is inconsistent with Moscow's view "which attaches great importance to close ties with Israel and considers Israeli security essential for the viability of its regional strategy. This partly explains why Moscow has mostly tried - to Tehran's frustration and occasional objections - to look the other way as Israel has continued to target Iran-linked positions and paramilitary forces in Syria and beyond.[52]"Moscow also does not rule out cooperation with the West and its allies, including the Zionist regime, Turkey, and Saudi Arabia, but Iran views some of these countries as "part of the problem", not "part of the solution" to the Syrian crisis[53].

According to some analysts, Russia, along with its close cooperation with Iran in Syria, also has some kind of competition with Iran in expanding its sphere of influence and determining the future of Syria[53]. Russia's interests in Syria are both economic and political.By deploying their forces in a region of the Mediterranean Sea where it could be the region's energy hub in the future after regional crises have subsided,the Russians are seeking a share of the energy mainstream, which means an inevitable competition with Iran[53].Given the Crimea crisis and even before that, Russia's military intervention in Georgia in 2008, Putin is strongly under pressure from the West[53]. In addition, the sanctions and reduced oil price have simultaneously hampered the Russian economy; therefore, Moscow is seeking to increase its cards in the game against the West, and Russia's military operation in Syria is one of those important cards[53].

\section{CONCLUSION}

When the crisis began in Syria, the cooperation between Iran and Russia gained significant momentum.During this crisis, Iran and Russia's parallel position took a new form, putting them for the first time in a joint operational front in the Middle East.Based on what was described in this research,Iran and Russia reached a level of effective military cooperation to eradicate ISIS and its affiliates, the major security threat to the region and the world. While Russia used its advanced air force and intelligence assistance, Iran used its IRGC Quds Force, and organized Hezbollah and other popular volunteer forces on the ground to fight against Takfiri terrorists. Arguably, the commonality between Iran and Russia's policy in Syria has several factors: Both states seem discontent with the current world order and US unilateralism in the regional and global issues. According to the 
discussions, the author tends to conclude that the political-military cooperation between Tehran and Moscow in Syria was mainly driven by a common sense of danger which threatened their national security, sphere of influence, and their strategic interests.

In addition, Russia is keen to fulfill its longstanding role as a decisive actor and great power in resolving global issues; thus, building a regional alliance or partnership with a country like Iran (which shares a number of security concerns with Moscow) makes sense for the Kremlin. Both Russia and Iran are working to prevent Libya's fate and its regime change model for other countries in the region. With a broad strategic view and by opposing the US unilateralism, Russia aims to create a multipolar world and redefine its role in the Middle East.

By reviewing Iran-Russia relationship, it can be inferred that Russia is interested in the long-term benefits and relative achievements of these partnerships with Iran, and is cautious about expanding its cooperation so as not to harm its strategic interests and its relationship with other regional actors.Therefore, Russia fears that expanding its cooperation with Iran would make Iran a serious competitor for it in the region. On the other hand, Iran also fears that Russia will conclude agreements with its rival countries, namely Saudi Arabia, UAE, and Israel and diminish Iran's role in regional equations.In an atmosphere of distrust in international relations, countries are wary of being deceived by their partners in building long-term alliance; however, the type and quality of Iran-Russia cooperation in Syria over the past few years rules out the possibility of sheer deception, but it is always possible that one partner strives to maximize its own interests and minimize those of its partner.

The author believes that the regional and international atmosphere and a common understanding of the threat in the Syrian crisis made Iran and Russia turn the threat into an opportunity to expand their military and political cooperation. Despite the cooperation between Moscow and Tehran, their differences on some issues in Syria cannot be ignored; however, the two partners' mission and mutual concerns and interests have made their differences less visible at present. Therefore, according to the research question that "whether the present cooperation between Iran and Russia in Syria will lead to a strategic alliance", the author intends to respond that as long as their main factors of cooperation persist, such cooperation may even have the potential to reach a strategic alliance. When the threat is eliminated and the level of operational and field cooperation naturally decreases, then in bilateral relations, "cooperation" might be replaced by a "competition" over one's own national interests.

\section{REFERENCES}

[1] .141 ‘1392

20

6، شماره

سال (Sheikhol Eslami, M. H., and Beiki, M., "An Analysis of Russian Federation's Role and Policy Towards the Syrian Crisis," Quarterly of Afaqe Amniat, Vol. 6, No. 20, Autumn 2013, 141.)

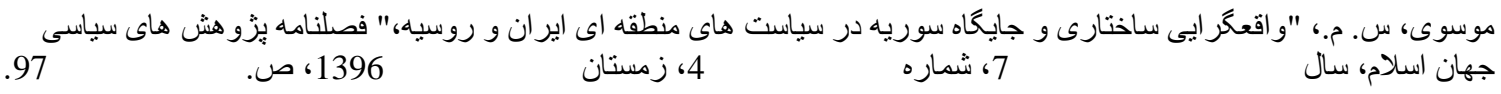

(Mousavi, S. M, "Structural Realism and Syria's Position in the Regional Policies of Iran and Russia," Quarterly Journal of Political Research in Islamic World, Vol. 7, No. 4, Winter 2017, 97.)

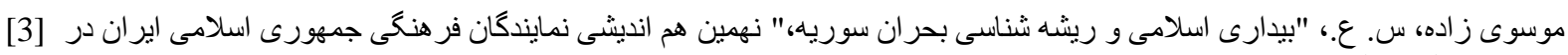

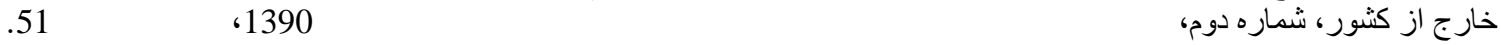
(Mousavizadeh, S. A., "Islamic Awakening and the Roots of Syrian Crisis," The Ninth Meeting of Iranian Cultural Representatives Abroad, second issue, 2011, 51.)

[4] Syrian National Council website, accessible at: https://en.etilaf.org/coalition-components/syrian-nationalcouncil.html

نياكويى، س. ا.، بهمنش، ح.،"بازيكر ان معارض در بحر ان سوريه: اهداف و رويكردها،" فصلنامه رو ابط خارجى، سال4، شماره 4، [5] .104

(Niakouyi, S. A., Behmanesh, H., "Conflicting Actors in the Syrian Crisis: Goals and Approaches," Quarterly of Foreign Relations, Vol. 4, No. 4, 2012, 104.)

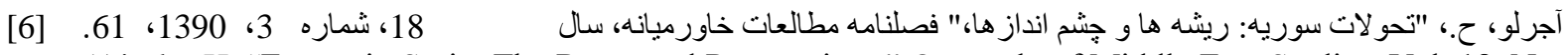
(Ajorlu, H.,"Events in Syria: The Roots and Perspectives," Quarterly of Middle East Studies, Vol. 18, No. 3, 2011, 61.)

[7] Cockburn, P., The Rise of Islamic State: ISIS and the New Sunni Revolution. (New York: Verso Books, 2015, p. 4), retrieved from http://www.kropfpolisci.com/isis.cockburn.pdf

[8] New World Encyclopedia, accessible at: https://www.newworldencyclopedia.org/entry/Wahhabism 
[9] A brief look at the ISIS' background and foundations of thought, retrieved from the website of Saghalein Cultural Institute: http://saghalein-ins.com/?p=331

[10] Cockburn, P., The Rise of Islamic State: ISIS and the New Sunni Revolution. (New York: Verso Books, 2015, p. 5), retrieved from http://www.kropfpolisci.com/isis.cockburn.pdf

ذو الفقارى، م.، عمر انى، ا.، "ناثير ظهور داعش بر امنيت ملى جمهورى اسلامى ايران،" فصلنامه يُزو هش هاى سياسى جهان اسلام، [11] سال (Zolfaghari, M., Omrani, A., "The Impact of ISIS on the National Security of the Islamic Republic of Iran," Quarterly of Islamic World Political Studies, Vol. 7, No. 2, summer 2017, 178.)

[12] "Four baby doll bombs discovered and defused in Kashmar", BBC Persian, 11 Dec 2015, accessible at: https://www.bbc.com/persian/iran/2015/12/151211_145_bombed_doll_kashmar_iran

[13] "ISIS plants baby doll boms on road to Karbala", The New Arab, 20 Nov 2015, retrieved from: www.alaraby.co.uk/english/amp/blog/2015/11/20/is-plants-baby-doll-bombs-on-road-to-karbala

[14] "Iran detains 6 persons linked to Tehran terror attacks" Tasnim News Agency, 11 Jun 2017, accessed from: www.tasnimnews.com/en/news/2017/06/11/1433203/iran-detains-6-persons-linked-to-tehran-terrorattacks

[15] "Iran targets terrorists in missile strike on ISIS-held Syrian town", The Guardian, 18 Jun 2017, accessed from: www.amp.theguardian.com/world/2017/jun/18/iran-targets-terrorists-in-missile-strike-on-isis-heldsyrian-town

[16] Korybko, A., "Iran: "State Sponsor of Terror" or Major Victim?” Sputnik, 07.06.2017, Accessible at: https://sputniknews.com/columnists/201706071054402900-iran-major-victim-of-terror/

[17] “ISIS Publishes A Map Illustrating Its Five-Year Plan For World Domination” Elite Daily, 30 Jun 2014, accessible at: https://www.elitedaily.com/news/politics/isis-publishes-map-illustrating-five-year-planworld-domination/650801

[18] Price, B., "Syria: A Wicked Problem For All," CTC Sentinel, 2013, 6, 8, 11, available on: http://www.ctc.usma.edu/wp-content/\%20uploads/2013/08/CTCSentinel-Vol6Iss8.pdf

عزيزى، ح.، نجفى، م.، "آينده شر اكت ايران و روسيه در بحر ان سوريه،" فصلنامه رهيافت هاى سياسى و بين المللى، سالو، شماره 2، [19] 70 1396 زمستان

(Azizi, H., Najafi, M., "The Future of Iran-Russia Partnership in the Syrian Crisis," Quarterly of Political and International Approaches, Vol. 9, No. 2, winter 2018, 70.)

موسوى، س. م.، "و اقعكر ايى ساختارى و جايگاه سوريه در سياست هاى منطقه اى اير ان و روسيه،" فصلنامه بِزو هش هاى سياسى [20]

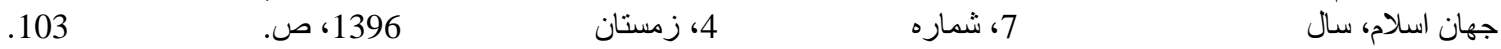
(Mousavi, S. M, "Structural Realism and Syria's Position in the Regional Policies of Iran and Russia," Quarterly Journal of Political Research in Islamic World, Vol. 7, No. 4, Winter 2017, 103.)

[21] Дугин,А., “Время объявить войну мировому правительству,” Евразия, информационно аналитический портал, 3 января 2013, доступно по адресу: http://evrazia.org/article/2184

(Dugin, A., "Time To Declare War on a World Government," Eurasia, Portal of Information and Analysis, 3 January 2013)

[22] Putin, V., "Russia and the Changing World," RT, 27 Feb 2012, retrieved from: https://www.rt.com/russia/official-word/putin-russia-changing-world-263/

نجات، س. ع.، جعفرى ولدانى، ا.،"بررسى جايحاه و نقش جمهورى اسلامى اير ان در بحر ان سوريه،" يزّو هش هاى سياسى، سال 3، [23]

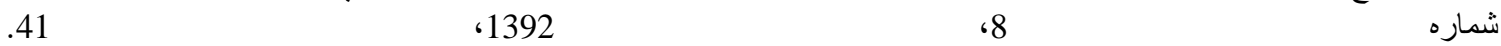
(Nejat, S. A., Jafari Voldani, A., "A Study of the Islamic Republic of Iran's Role in the Syrian Crisis," Journal of Political Studies, Vol. 3, No. 8, 2013, 41.)

موسوى، س. م.، "و اقعكر ايى ساختارى و جايگاه سوريه در سياست هاى منطقه اى اير ان و روسيه،" فصلنامه بِزو هش هاى سياسى [24]

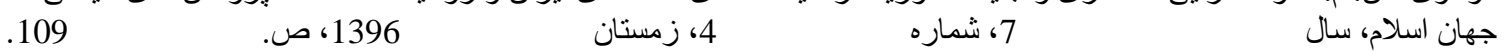

(Mousavi, S. M, "Structural Realism and Syria's Position in the Regional Policies of Iran and Russia," Quarterly Journal of Political Research in Islamic World, Vol. 7, No. 4, Winter 2017, 109.)

نجات، س. ع.، جعفرى ولدانى، ا.، "بررسى جايگاهو نقش جمهورى اسلامى اير ان در بحران سوريه،" بِزو هش هاى سياسى، سال 3، [25]

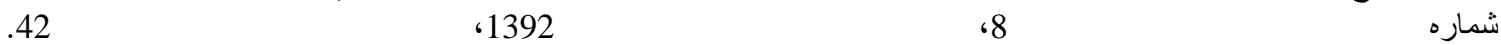
(Nejat, S. A., Jafari Voldani, A., "A Study of the Islamic Republic of Iran's Role in the Syrian Crisis," Journal of Political Studies, Vol. 3, No. 8, 2013, 42.)

سيمبر ، ر.، قاسميان، ر.، "مولفه هاى اساسى محيط امنيتى اير ان و سوريه،" فصلنامه بِزو هش هاى ر اهبردى سياست، سالق، شماره 9، [26] .155 ، 1393

(Simbar, R., Qasemiyan, R., "Basic Components of the Security Environment of Iran and Syria," Quarterly of Strategic Research of Politics, Vol. 3, No. 9, summer 2014, 155.) 
زمزيزى، ح.، نجفى، م.، "آينده شر اكت ايران و روسيه در بحر ان سوريه،" فصلنامه رهيافت هاى سياسى و بين المللى، سالو، شماره2، [27 (Azizi, H., Najafi, M., “The Future of Iran-Russia Partnership in the Syrian Crisis,” Quarterly of Political and International Approaches, Vol. 9, No. 2, winter 2018, 75.)

[28] The Foreign Policy Concept of the Russian Federation, June 28, 2000, https://fas.org/nuke/guide/russia/doctrine/econcept.htm

[29] Baev, P. K., "Defying That Sinking Feeling: Russia Seeks To Uphold Its Role In The Multistructural International System In Flux," in Perspectives on Russian Foreign Policy, Stephen J. Blank, Strategic Studies Institute Newsletter, September 2012, p.2.

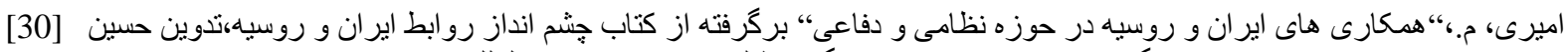

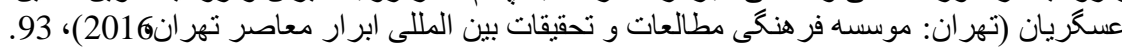

(Amiri, M., "Iran-Russia Military and Defense Cooperation" in Future Outlook of Iran-Russia Relations, ed. Hossein Asgarian (Tehran: International Strudies \& Research Institute of Abrar Moaser Tehran, 2016), 93.

[31] Ian K., “A New Phase in Russia-Iran Relations," Georgetown Security Studies Review, 16 October 2015, accessible at: https://georgetownsecuritystudiesreview.org/2015/10/16/a-new-phase-in-russia-iranrelations/

[32] Бовт, Г., “Афганистаном Сирия не станет,” Совет По Внешней И Оборонной Политике, 16 сентябрь 2015, доступно по адресу: http://svop.ru/main/16550/

(Bovt, G., "Syria Will Not Become Afghanistan," The Council On Foreign And Defense Policy, 16 September 2015)

[33] Lyengar, R., "The Conflict in Syria: An Assessment of US Strategic Interests," New America Foundation, 2013, 7.

شيخ الاسلامى، م. ح.، و بيكى، م، "و اكاوى نقش آفرينى و سياست هاى فدر اسيون روسيه در قبال بحر ان سوريه،" فصلنامه آفاق امنيت، [34] .157 ،1392

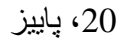

$$
\text { 6، شماره }
$$

(Sheikhol Eslami, M. H., and Beiki, M., “An Analysis of Russian Federation's Role and Policy Towards the Syrian Crisis," Quarterly of Afaqe Amniat, Vol. 6, No. 20, Autumn 2013, 157.)

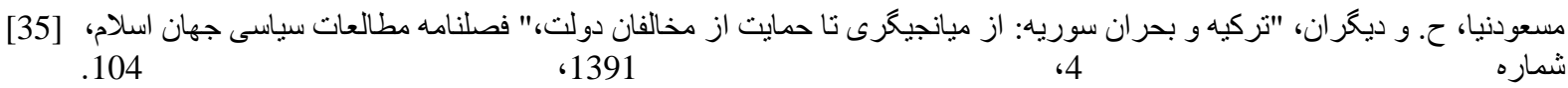

(Masoudnia, H. et al., "Turkey and the Syrian Crisis: From Mediation to Supporting Assad's Opposition Forces," Quarterly Journal of Political Research in Islamic World, No. 4, 2013, 104.)

[36] Лавров, С.“Россия хочет, чтобы Сирия избежала судьбы Ливии,” Ведомости, 02 декабря 2016 , доступно по адресу: https:/www.vedomosti.ru/politics/news/2016/12/02/667974-rossiya-hochet-chtobi (Lavrov, S., "Russia Wants Syria to Avoid the Fate of Libya," Vedomosti, 2 December 2016)

[37] Roy, A., "Explaining Alignment with a Regime in Crisis," International Affairs, (89), 4, 2013, 804

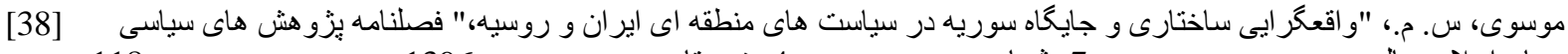

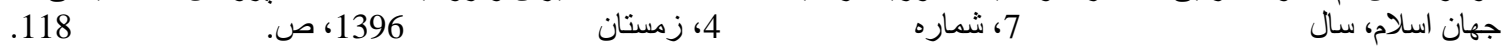
(Mousavi, S. M, "Structural Realism and Syria's Position in the Regional Policies of Iran and Russia," Quarterly Journal of Political Research in Islamic World, Vol. 7, No. 4, Winter 2017, 118.)

[39] Roy, A., "Explaining Alignment with a Regime in Crisis," International Affairs, (89), 4, 2013, 807.

[40] Trenin, D., “The Mythical Alliance: Russia’s Syria Policy,” Carnegie Moscow Center, 2013, 3.

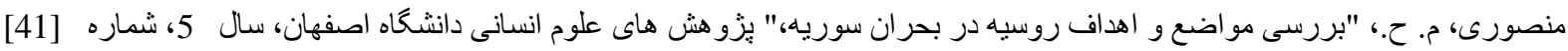

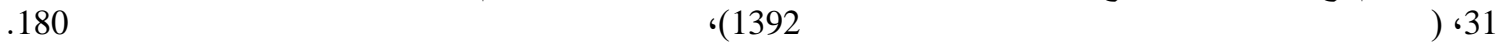
(Mansouri, M. H., “A Study of Russia's Stance and Goals in the Syrian Crisis," University of Isfahan Humanities Research, Vol. 5, No. 31 (2013), 180.)

[42] "Referral of Syria to International Criminal Court Fails as Negative Votes Prevent Security Council from Adopting Draft Resolution," United Nations Meetings Coverage and Press Releases, 22 May 2014, retrieved from: www.un.org/press/en/2014/sc11407.doc.htm

عزيزى، ح.، نجفى، م.، "آينده شر اكت ايران و روسيه در بحر ان سوريه،" فصلنامه رهيافت هاى سياسى و بين المللى، سالو، شماره 2، [43] زمستان (Azizi, H., Najafi, M., "The Future of Iran-Russia Partnership in the Syrian Crisis," Quarterly of Political and International Approaches, Vol. 9, No. 2, winter 2018, 80.)

[44] “Роль России в урегулировании вооруженного конфликта в Сирии. Досье,”ТАСС, 30 АВГ 2015, доступны по адресу: https://tass.ru/info/889036

(Russia's Role in Resolving the Armed Conflict in Syria. Dossier, TACC, 30 August 2015)

[45] Косачев,К, "боевое братство" РФ и Ирана в Сирии получило поддержку на высшем уровне, ТАСС, 29 МАР 2017, доступны по адресу:https://tass.ru/politika/4133657

(Kosachev,K., "The "brotherly fight" of the Russian Federation and Iran in Syria received top-level support," TACC, 29 March 2017) 
[46] “Путин назвал продуктивной совместную работу с Ираном по сирийской проблеме,” ТАСС, 1 НОЯ 2017, доступны по адресу:https://tass.ru/politika/4695832

(Putin Called the Collaboration With Iran on Syrian Crisis As "Productive",TACC, 1 Nov 2017)

[47] “Рябков: между РФ и Ираном нет противоречий по Сирии,” ТАСС, 1 НОЯ 2017, доступны по адресу: https://tass.ru/politika/4693656

(Ryabkov: There Are No Contradictions Between Russia and Iran over Syria, TACC, 1 Nov 2017)

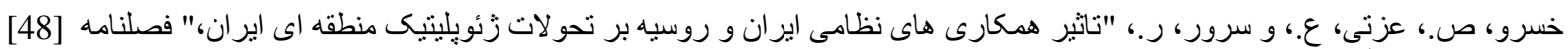

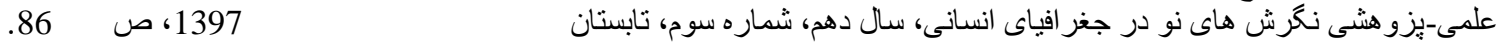
(Khosro, S., Ezzati, E., Sarvar, R., "The Impact of Iran-Russia Military Cooperation on Regional Geopolitical Developments," Scientific \& Research Journal of New Approaches in Human Geography, Vol. 10, No. 3, summer 2018, p. 86.)

[49] Lavrov, S., "Lavrov to Sputnik: Assad Not Moscow's Ally Like Ankara is to Washington," Sputnik, 4May 2016, accessible at:https://sputniknews.com/politics/201605041039060941-assad-russia-ally-lavrov/

جعفرى، م. ع.، "مذاكره با امريكا جيزى جز ضرر ندارد،" خبركزارى فارس، (Jafari, M. A., "There is nothing in negotiating with the US but harm”, Fars News Agency, 2 Nov 2014, accessible at shortened link: https://b2n.ir/785286"

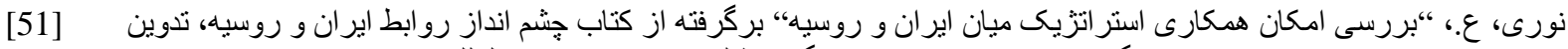

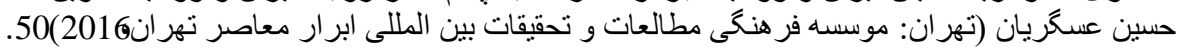

(Nouri, A., "Examining the Possibility of a Strategic Cooperation Between Iran and Russia" in Future Outlook of Iran-Russia Relations, ed. Hossein Asgarian (Tehran: International Strudies \& Research Institute of Abrar Moaser Tehran, 2016), 50.)

[52] Behravesh, M., “Can Russian-Iranian alignment in Syria last?”, Middle East Institute, 16 Oct 2019 , accessible at: https://www.mei.edu/publications/can-russian-iranian-alignment-syria-last

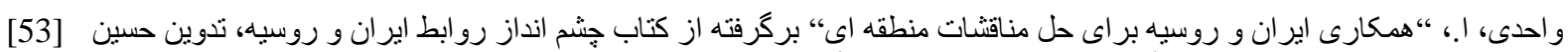

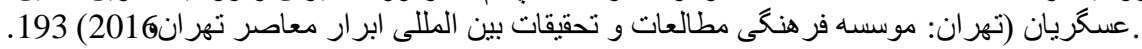

(Vahedi, E., "Iran-Russia Cooperation over Regional Conflicts" in Future Outlook of Iran-Russia Relations, ed. Hossein Asgarian (Tehran: International Strudies \& Research Institute of Abrar Moaser Tehran, 2016), 193.)

Citation: Reza Piramoun Sharifabad. "A Research Into Iran-Russia Cooperation During the Syrian Crisis" International Journal of Political Science (IJPS), vol 6, no.2, 2020, pp. 1-11. doi: http://dx.doi.org/10. 20431/2454-9452.0602001.

Copyright: () 2020 Authors. This is an open-access article distributed under the terms of the Creative Commons Attribution License, which permits unrestricted use, distribution, and reproduction in any medium, provided the original author and source are credited. 